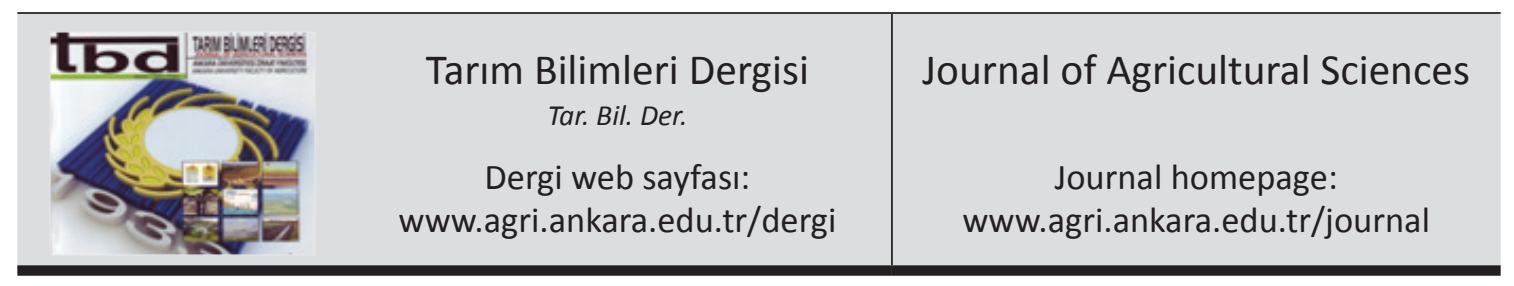

\title{
Fosfor Çözücü Bakteri, Fosforlu Gübre ve Tavuk Gübresi Uygulamalarının Macar Fiğinde (Vicia Pannonica Roth) Tohum Verimi ve Verim Unsurları Üzerine Etkileri
}

\author{
Dilara FAYETÖRBAY ${ }^{\text {a }}$, Binali ÇOMAKLI ${ }^{\mathrm{a}}$, Mahmut DAŞCI ${ }^{\mathrm{a}}$ \\ aAtatürk Üniversitesi, Ziraat Fakültesi, Tarla Bitkileri Bölümü, 25240, Erzurum, TÜRKIYE
}

ESER BILGİSi

Araştırma Makalesi

DOI: 10.1501/Tarimbil 0000001293

Sorumlu Yazar: Dilara FAYETÖRBAY, E-posta: dorbay@atauni.edu.tr, Tel: +90 (442) 2312529

Geliş Tarihi: 20 Mayıs 2013, Düzeltmelerin Gelişi: 14 Şubat 2014, Kabul: 26 Mart 2014

\section{ÖZET}

Baklagil yem bitkileri azot ihtiyaçlarını simbiyotik yolla karşılayabildiğinden fosforlu gübrelemeye iyi tepki verirler. Diğer yandan kimyasal gübrelerin fiyatının artması e çevre kirliliğine sebep olmasına bağlı olarak çevreye dost alternatif fosfor kaynaklarına ilgi artmıştır. Erzurum sulu şartlarında 2009-2010 yılları arasında yürütülen bu çalışmada tek doz fosfat çözücü bakteri (Bacillus megaterium $\left.M-3,10^{-8} \mathrm{CFU} \mathrm{ml}^{-1}\right), 2$ farklı dozda $\left(0.3 \mathrm{t} \mathrm{ha}^{-1}\right)$ tavuk gübresi ve 3 farklı dozda $\left(0,50,100 \mathrm{~kg} \mathrm{P}_{2} \mathrm{O}_{5} \mathrm{ha}^{-1}\right)$ uygulanan fosforlu gübrenin Macar fiğinde tohum verimi ve verim unsurları üzerine etkileri ele alınmıştır. Bakla sayısı ortalama 13.58 adet; ana dal sayısı 2.01 adet; baklada tane sayısı 4.58 adet; 1000 tane ağırlığı 32.93 gr ve tohum verimi ise $1.59 \mathrm{t} \mathrm{ha}^{-1}$ olarak belirlenmiştir. Bu sonuçlara göre Erzurum gibi yüksek rakımlı ve fosfor yönünden fakir veya orta topraklara sahip alanlarda suluda Macar fiğinde tohum üretmek için $100 \mathrm{~kg} \mathrm{ha}^{-1} \mathrm{P}_{2} \mathrm{O}_{5}$ uygulamasına ilaveten fosfor çözücü bakteri ve 3 ton ha-1 tavuk gübresi uygulaması yüksek verim için uygun olacaktır. Anahtar Kelimeler: Fosfor çözücü bakteri; Fosforlu gübre; Tavuk gübresi; Vicia pannonica Roth; Tohum verimi; Verim unsurlar1

\section{Effects of Phosphorus Solubilizing Bacteria, Phosphorus Fertilizer and Poultry Manure Treatments on The Seed Yield and Yield Components of Hungarian Vetch (Vicia Pannonica Roth)}

\author{
ARTICLE INFO \\ Research Article \\ Corresponding Author: Dilara FAYETORBAY, E-mail: dorbay@atauni.edu.tr, Tel: +90 (442) 2312529 \\ Received: 20 May 2013, Received in Revised Form: 14 February 2014, Accepted: 26 March 2014
}

\section{ABSTRACT}

Legumes give good response to phosphorus fertilizer because they obtained required nitrogen via symbiotic way. On the other and, some problems such as increasing prices and environmental pollution related to chemical phosphorus fertilizer, increased interest in alternative and environmental friendly phosphorus resources. This study was carried out 
to determine the effects of phosphorus solubilizing bacteria (Bacillus megaterium $M-3,10^{-8} \mathrm{CFU} \mathrm{ml}^{-1}$ ), two different doses of poultry litter $\left(0.3 \mathrm{tha}^{-1}\right)$ and three different doses of phosphorus fertilizer $\left(0,50,100 \mathrm{~kg} \mathrm{P}_{2} \mathrm{O}_{5}\right.$ ha $\left.^{-1}\right)$ treatments on seed yield and yield components of Hungarian vetch. Experiments were carried out under irrigated conditions of Erzurum, between the years 2009 and 2010. Number of pods per plant 13.58, the number of branches 2.01, the number of seeds per pod 4.58, 1000-grain weight 32.93 and seed yield $1.59 \mathrm{t} \mathrm{ha}^{-1}$ was reported, respectively. According to these results, plus phosphorus solubilizing bacteria and $100 \mathrm{~kg} \mathrm{P}_{2} \mathrm{O}_{5}$ ha $^{-1}$ and poultry litter may be recommended for higher seed yields of Hungarian vetch for places such as Erzurum, a high altitude semiarid environment and in terms of phosphorus poor or moderate.

Keywords: Phosphorus solubilizing bacteria; Phosphorus fertilizer; Poultry manure; Vicia pannonica Roth; Seed yield; Yield parameters

(C) Ankara Üniversitesi Ziraat Fakültesi

\section{Giriş}

Hayvan besleme açısından ön plana çıkan baklagil yem bitkilerinin ekiliş alanı ve üretim miktarının artırılması bölgeye uygun tür ve çeşitlerin geliştirilmesi ve bunların yaygınlaştırılması için yeterince tohumun üretilmesi veya temini ülke ve bölge hayvancılığı açısından önem arz etmektedir. Baklagiller familyası içerisinde yer alan fiğ türleri içerisinde soğuğa dayanıklı olan Macar fiği yetiştiriciliği bölge şartlarına uyum problemi olmaması (Tahtacıoğlu et al 1996) ayrıca otunda ve tanesinde yüksek ham protein oranına sahip olması nedeniyle hayvan beslenmesinde oldukça önemli bir yem bitkisidir (Tan \& Serin 2013).

Baklagiller köklerindeki Rhizobium bakterileri sayesinde havanın azotunu bağladıklarından azotlu gübrelemeye çok ihtiyaç duymazken, özellikle fosforlu gübrelemeye iyi tepki verirler. Fosfor uygulamasına bağlı olarak artan kök gelişimi ile kökün topraktaki temas yüzeyi artmakta, böylece bitkilerin diğer besin maddelerinden yararlanma oranları artmaktadır (Marschner 1995). Fosforlu gübrelere iyi tepki veren Macar fiğinde yüksek verim için ihtiyaç duyduğu fosfor organik ya da inorganik yolla sağlanmalıdır. Ancak kimyasal gübrelerin bilinçsiz kullanımından ve çevreye zararlı etkilerinden dolayı daha az ve dikkatli kullanılmaları ya da bunlara alternatif olabilecek organik ürünlerin kullanımı giderek önem kazanmaktadır (Orson 1996). Tavuk gübresi fosfor, azot ve diğer besin elementleri bakımından zengin, toprakların fiziksel özelliklerini ve verimliliğini geliştiren önemli bir organik bir gübre kaynağıdır (Ano \& Agwu 2005).

Bitkiler genel olarak topraktaki toplam fosforun sadece \%1'inden faydalanabilirler (Scheffer \& Schachtschabel 1992). Toprakta serbest yaşayan ve "bitki gelişiminini teşvik eden rizobakteriler" BGTB adı verilen mikroorganizmalar enzim ve hormon sentezini değiştirerek, bitki besin elementi alımını artırarak bitki büyümesini teşvik etmektedir (Şahin et al 2004; Yolcu et al 2012). Bu nedenle bakteri aşılamasının kimyasal gübrelerle beraber kullanılabileceği ya da kimyasal gübre kullanımına bir alternatif olabileceği düşünülmektedir (Çakmakcı et al 1999). Uzunmehmetoğlu \& Kendir (2006), Ankara koşullarında kışlık yetiştirilen koca fiğin (Vicia narbonensis L.) değişik hatları ile kışlık ve yazlık ekimin tane verimi ile bazı bitkisel özellikler üzerine olan etkilerini incelemişlerdir.

Enerji fiyatlarındaki artışa bağlı olarak fosforlu gübre fiyatların sürekli artmasının yanında fosforlu gübrelerin kadmiyum içermesi nedeniyle çevreye zararlı olmaları, tarımda sürdürülebilirliği ön plana çıkarmıştır. Bu doğrultuda fosforlu gübreye alternatif arayışı hızlanmıştır. Bu çalışmanın amacı Macar fiğinde yüksek verim için uygun fosforlu gübre dozunun belirlenmesi ve fosfor çözücü bakterinin yalnız veya tavuk gübresi ile birlikte uygulanmasının kimyasal gübreye alternatif olup olamayacağı sorusuna cevap bulmak olmuştur. 


\section{Materyal ve Yöntem}

Araştırma, Erzurum'da Atatürk Üniversitesi Ziraat Fakültesi Tarımsal Araştırma ve Yayım Merkezi Müdürlüğüne ait 4 no'lu kuyu deneme alanında 2009 ve 2010 yıllarında yürütülmüştür. Toprakların tekstürleri Bouyoucus hidrometre yöntemiyle (Gee \& Hortage 1986) iki yılda da tın sınıfinda belirlenmiştir. pH'ları 1:2.5'luk topraksu süspansiyonunda potansiyometrik olarak cam elektrotlu pH metre ile (McLean 1982) ilk y1 7.45, ikinci yıl 7.65 belirlenmiştir. Kireç içerikleri Scheibler kalsimetresi ile volümetrik olarak (Nelson 1982) ilk yıl \% 0.82, ikinci yıl \% 0.85 saptanmıştır. Toprakların organik madde içerikleri SmithWeldon yöntemiyle (Nelson \& Sommers 1982) ilk y11 \% 1.40, ikinci yıl \% 1.80 belirlenmiştir. Fosfor içerikleri Molibdofosforik mavi renk yöntemine göre oluşturulan mavi renkli çözeltinin 1şık absorbsiyonu $660 \mathrm{~nm}$ dalga boyuna ayarlı spektrofotometrede okunarak (Olsen \& Summers 1982) ilk y1l $27.5 \mathrm{~kg}$ ha $^{-1}$, ikinci yıl $62 \mathrm{~kg} \mathrm{ha}^{-1}$ belirlenmiştir. Potasyum içeriği alevli fotometre yöntemiyle (Thomas 1982) ilk yıl $118 \mathrm{~kg} \mathrm{ha}^{-1}$ ikinci yıl $158 \mathrm{~kg} \mathrm{ha}^{-1}$ olarak belirlenmiştir.
Deneme sahasının yıllık toplam yağış miktarı uzun yıllar ortalamasına göre $410.2 \mathrm{~mm}$, denemenin ilk y1lında $437.8 \mathrm{~mm}$, ikinci y1lında $475.9 \mathrm{~mm}$ olarak gerçekleşmiş olup uzun yıllar ortalamasının üzerinde seyretmiştir. Denemenin ilk yılında Mart, Haziran, Ekim ayları, ikinci yılında ise Mart, Mayıs ve Ekim ayları daha yağışlı geçmiştir (Çizelge 1).

Uzun y1llar (1929-2009) ortalamas $5.3{ }^{\circ} \mathrm{C}$ olan sicaklık deneme yıllarında sirasiyla $5.8^{\circ} \mathrm{C}$ ve $7.9^{\circ} \mathrm{C}$ olup uzun yıllar ortalamasının üzerinde seyretmiştir. Özellikle ikinci yılda belirgin bir yükselme görülmüştür. İlk yıl en yüksek sıcaklık 17.2 ile Temmuz ayında, ikinci yıl ise 20.3 ile Ağustos ayında tespit edilmiştir. Nispi nem değerleri ise uzun yıllar ortalamasina göre \% 65.4 ve deneme yıllarında sirasıyla \% 68.2 ve $\% 66.5$ olarak belirlenmiştir. Bitkinin aktif büyüme dönemi olan Mayıs-Temmuz dönemi aylık nispi nem ortalaması ilk yılında Mayıs ayında uzun yıllar ortalamasına göre düşük seyrederken Haziran ve Temmuz aylarında yüksek belirlenmiş, ikinci yılında ise uzun yıllar ortalamasının üzerinde olmuştur.

Araştırma şansa bağlı tam bloklar deneme deseninde faktöriyel düzenlemeye göre 3 tekerrürlü olarak kurulmuştur. Her parsele $3 \mathrm{~m}$

Çizelge 1- Erzurum ilinde 2009, 2010 ve uzun yıllar ortalamasına ait yağış sıcaklık ve nispi nem değerleri Table 1-2009, 2010 and long-term average values of rain fall, temperature and relative humidity values in Erzurum province

\begin{tabular}{|c|c|c|c|c|c|c|c|c|c|}
\hline \multirow{2}{*}{ Aylar } & \multicolumn{3}{|c|}{ Aylık toplam yă̆lş (mm) } & \multicolumn{3}{|c|}{ Aylık ortalama sicaklık $\left(C^{o}\right)$} & \multicolumn{3}{|c|}{ Aylık ortalama nispi nem (\%) } \\
\hline & 2009 & 2010 & $U Y O$ & 2009 & 2010 & $U Y O$ & 2009 & 2010 & $U Y O$ \\
\hline Ocak & 2.3 & 52.2 & 19.8 & -12.1 & -4.3 & -9.7 & 82.4 & 84.0 & 77.0 \\
\hline Şubat & 18.8 & 14.8 & 24.8 & -3.1 & -1.8 & -8.6 & 84.7 & 82.3 & 77.0 \\
\hline Mart & 51.1 & 82.2 & 31.0 & -0.7 & 3.1 & -2.8 & 73.8 & 69.1 & 75.0 \\
\hline Nisan & 42.7 & 54.2 & 58.4 & 4.3 & 5.6 & 5.4 & 64.6 & 71.3 & 66.0 \\
\hline May1s & 43.2 & 63.6 & 70.0 & 10.0 & 10.4 & 10.5 & 61.0 & 69.6 & 63.0 \\
\hline Haziran & 76.2 & 50.5 & 41.6 & 14.7 & 15.9 & 14.9 & 65.0 & 60.1 & 58.0 \\
\hline Temmuz & 29.2 & 55.5 & 26.2 & 17.2 & 19.5 & 19.3 & 60.7 & 56.0 & 52.0 \\
\hline Ağustos & 22.8 & 9.0 & 15.1 & 17.1 & 20.3 & 19.4 & 50.6 & 44.8 & 49.0 \\
\hline Eylül & 43.7 & 8.8 & 20.0 & 12.4 & 17.0 & 14.3 & 53.1 & 48.1 & 52.0 \\
\hline Ekim & 51.0 & 72.2 & 47.9 & 8.7 & 9.2 & 7.6 & 62.4 & 70.2 & 65.0 \\
\hline Kasım & 41.4 & 0.0 & 32.9 & 1.8 & 1.8 & -0.1 & 75.7 & 66.1 & 73.0 \\
\hline Aralık & 15.4 & 12.9 & 22.5 & -1.1 & -1.9 & -6.6 & 84.7 & 76.6 & 78.0 \\
\hline Top/Ort & 437.8 & 475.9 & 410.2 & 5.8 & 7.9 & 5.3 & 68.2 & 66.5 & 65.4 \\
\hline
\end{tabular}

Çizelgedeki veriler Erzurum Meteoroloji Bölge Müdürlüğü'nde alınmıştır 
uzunluğunda 6 sıra bitki ekilerek ve sıra aralığ $30 \mathrm{~cm}$ (Tan \& Serin 2013) olarak planlanmıştır. Deneme 0,50 ve $100 \mathrm{~kg} \mathrm{P}_{2} \mathrm{O}_{5}$ ha $^{-1}$ dozlarında kimyasal gübre (Triple süper fosfat), 0 ve 3000 $\mathrm{kg}$ ha-1 dozlarında tavuk gübresi ve fosfor çözücü bakteri (Bacillus megaterium) aşılamasını içermektedir. Bacillus megaterium aşılaması inkübasyondan sonra $10^{8} \mathrm{CFU} \mathrm{ml}^{-1}$ yoğunluğunda hazırlanmış ve bakteri aşılaması parsellerine ekilecek tohumlara aşılanmıştır. Denemede bütün parsellere ekilecek tohumlar ekim öncesi Ankara Toprak ve Gübre Araştırma Enstitüsünden temin edilen Rhizobium leguminosarum bakterisi ile aşılanmıştır. Fosforlu gübre ve tavuk gübresi tırmıkla toprağa karıştırılmıştır. $8 \mathrm{~kg} \mathrm{da}{ }^{-1}$ Macar fiği tohumları her iki deneme yılında da (16 Eylül 2009 ve 2010) sonbaharda önceden hazırlanmış tohum yatağına 4-6 cm derinliğe (Tan \& Serin 2013) el mibzeri ile ekilmiştir. Fosfor çözücü bakteri (Bacillus megaterium) ile aşılanmış olan tohumlar bulaşmanın olmaması için farklı el mibzerleri kullanılmıştır. Parseller iki yılda da 3 kez büyüme sezonunda topraktaki nem eksikliğinden dolayı bitkilerin rengi koyu yeşile döndüğünde sulama yapılmıştır. Parsellerin başlarından $0.5 \mathrm{~m}$ ve kenarlarından birer sıra kenar tesiri olarak atıldıktan sonra bitkilerde alt baklalar kahverengiye dönmeye başlayınca tohum hasadı yapılmıştır (Tan \& Serin 2013). Tesadüfen seçilen 10 bitkide ana sap ve kardeşlerde bulunan toplam bakla sayısı sayılmış (Ekiz 1983) ve yine seçilen 10 bitkide ana sapta ilk baklanın çıktığı boğumdan bir sonraki boğumda bulunan baklalardaki taneler sayılmış (Sümerli et al 2002) sonuçları adet olarak tespit edilmiştir. İlk y1l 5 Ağustos, ikinci yıl ise 30 Temmuz'da hasat yapılmıştır. Daha sonra hasat edilen bitkiler harmanlandiktan sonra elde edilen tohumları tartılarak verimleri $\mathrm{kg} \mathrm{ha}^{-1}$ cinsinden belirlenmiştir. Her parselden elde edilen tohumlardan 4 tekrarlamalı olarak 100 adet tohum sayılmış ve hassas terazide tartılarak ortalaması alınmış ve sonucunun 10 ile çarpılmak suretiyle 1000 tane ağırlığı hesaplanmıştır (Şehirali 1997).

Araştırmada elde edilen verilerin JMP bilgisayar paket programında varyans analizine tabi tutulmuştur (SAS Institute 2002). Ortalamaların karşılaştırılmasında LSD testi kullanılmıştır (Yıldız \& Bircan 1994).

\section{Bulgular ve Tartışma}

BGTB uygulamasının bakla sayısına etkisi önemsiz olarak belirlenmiştir (Çizelge 2). Artan fosfor dozlarıla beraber bitkide bakla sayısı istatistiksel olarak önemli $(\mathrm{P}<0.01)$ seviyede artmış ve en yüksek değer (15-16 adet) ile hektara $100 \mathrm{~kg} \mathrm{P}_{2} \mathrm{O}_{5}$ uygulamasıyla elde edilmiştir. Fosfor bitkide daha çok generatif gelişmeyi teşvik ettiğinden (Yıldız 2008) dolay1 fosforlu gübrelemeyle bakla sayıs1 artmış olabilir. Nitekim fosforlu gübrelemenin bakla sayısı artırdığı önceki çalışmalarda da belirlenmiştir (Taş 1996; Maqsood et al 2001; Kadığlu 2011).

Tavuk gübresi uygulaması bitkide bakla sayısını önemli $(\mathrm{P}<0.01)$ seviyede artırmıştır. Yine yıllar arasında bitkide bakla sayısı yönünden önemli $(\mathrm{P}<0.01)$ fark çıkmıştır. İkinci yıldaki değerler ilk yıla göre daha yüksek olmuştur. İkinci yıldaki artış denemenin ikinci yılında toprakların fosfor yönünden daha zengin olmasından kaynaklanabilir. Tavuk gübresi azot ve fosfor başta olmak üzere besin elementlerince zengin bir organik gübredir. İçerdiği besin elementine ilaveten organik madde kapsamı sayesinde toprağın fiziksel yapısını da iyileştirdiği için ortamı bitki gelişmesi açısından daha elverişli hale getirmesi sonucu bitkiler daha fazla bakla meydana getirmiş olabilirler. Nitekim yapılan çalışma da da tavuk gübresi uygulamasının bakla sayısını artırdığg belirlenmiştir (Subrahmaniya et al 1999).

Tavuk gübresi uygulanmayan parsellerde BGTB uygulaması bakla sayısını azaltırken, tavuk gübresiyle beraber bakteri aşılaması bakla sayısını artırmıştır. Bu farklı tepki sonucu B x TG interaksiyonu önemli olmuştur (Şekil 1a). Bu durum muhtemelen tavuk gübresi uygulamasıyla toprak organik maddesi ve besin elementi içeriğinin artmasıyla bakteri etkinliğinin hızlanmasından kaynaklanmış olabilir. Nitekim yapılan çalışmada bakteri aşılamasının etkinliği bakteri suşu, toprak organik maddesi ve besin elementi içeriği, 
Çizelge 2- BGTB, tavuk gübresi ve fosforlu gübre uygulamalarının Macar fiğinde (Vicia pannonica) bakla sayısı (BS), ana dal sayısı (ADS), baklada tane sayısı (BTS), 1000 tane ağırlığı (1000 TA) ve tohum verimine (TV) etkisi

Table 2- Effects of BGTB, chicken manure and phosphorus fertilizer applications on number of pods (NP), number of main branches (NMB), seed number per pod (SNP), 1000-grain weight (1000 GW) and seed yield (SY) in Hungarian vetch (Vicia pannonica)

\begin{tabular}{|c|c|c|c|c|c|c|}
\hline & & $B S$ (adet) & $A D S$ (adet) & BTS (adet) & $1000 T A(g)$ & $T V\left(t h a^{-1}\right)$ \\
\hline \multirow{3}{*}{ BGTB (B) } & B0 & 13.55 & $1.88^{\mathrm{B}}$ & $4.61^{\mathrm{A}}$ & $32.77^{b}$ & $1.52^{\mathrm{B}}$ \\
\hline & B1 & 13.61 & $2.14^{\mathrm{A}}$ & $4.56^{\mathrm{B}}$ & $33.10^{\mathrm{a}}$ & $1.67^{\mathrm{A}}$ \\
\hline & Ortalama & 13.58 & 2.01 & 4.58 & 32.93 & 1.59 \\
\hline \multirow{4}{*}{$\begin{array}{l}\text { Fosforlu } \\
\text { Gübre (P) }\end{array}$} & P0 & $12.12^{\mathrm{C}}$ & $1.87^{\mathrm{b}}$ & $4.19^{\mathrm{C}}$ & $31.00^{\mathrm{C}}$ & $1.43^{\mathrm{C}}$ \\
\hline & P50 & $13.45^{\text {B }}$ & $2.00^{\mathrm{ab}}$ & $4.64^{\mathrm{B}}$ & $32.66^{\mathrm{B}}$ & $1.55^{\mathrm{B}}$ \\
\hline & P100 & $15.16^{\mathrm{A}}$ & $2.16^{\mathrm{a}}$ & $4.93^{\mathrm{A}}$ & $35.15^{\mathrm{A}}$ & $1.79^{\mathrm{A}}$ \\
\hline & Ortalama & 13.58 & 2.01 & 4.58 & 32.93 & 1.59 \\
\hline \multirow{3}{*}{$\begin{array}{l}\text { Tavuk gü- } \\
\text { bresi } \\
\text { (TG) }\end{array}$} & TG0 & $13.13^{\mathrm{B}}$ & 1.94 & $4.47^{\mathrm{B}}$ & 32.86 & 1.58 \\
\hline & TG1 & $14.02^{\mathrm{A}}$ & 2.08 & $4.71^{\mathrm{A}}$ & 33.01 & 1.60 \\
\hline & Ortalama & 13.58 & 2.01 & 4.58 & 32.93 & 1.59 \\
\hline \multirow{17}{*}{ Y1l (Y) } & 2009 & $10.72^{\mathrm{B}}$ & 2.00 & $4.57^{\mathrm{B}}$ & $32.73^{b}$ & $1.43^{\mathrm{B}}$ \\
\hline & 2010 & $16.44^{\mathrm{A}}$ & 2.02 & $4.60^{\mathrm{A}}$ & $33.15^{\mathrm{a}}$ & $1.75^{\mathrm{A}}$ \\
\hline & Ortalama & 13.58 & 2.01 & 4.58 & 32.93 & 1.59 \\
\hline & B & ns & $* *$ & $* * *$ & $*$ & $* * *$ \\
\hline & $\mathrm{P}$ & $* * *$ & $*$ & $* * *$ & $* *$ & $* * *$ \\
\hline & TG & $* * *$ & ns & $* * *$ & ns & $\mathrm{ns}$ \\
\hline & $\mathrm{Y}$ & $* *$ & ns & $* *$ & $*$ & $* * *$ \\
\hline & $\mathrm{B} \times \mathrm{P}$ & ns & ns & $* * *$ & ns & $* * *$ \\
\hline & $\mathrm{B} \times \mathrm{TG}$ & $* *$ & $\mathrm{~ns}$ & $* * *$ & ns & $* *$ \\
\hline & $B \times Y$ & ns & ns & ns & ns & ns \\
\hline & TG $\times$ P & ns & ns & $* * *$ & ns & $* * *$ \\
\hline & TG xY & ns & ns & $\mathrm{ns}$ & ns & $* *$ \\
\hline & $\mathrm{P} \times \mathrm{Y}$ & $* *$ & ns & ns & ns & ns \\
\hline & B x P x TG & ns & $* *$ & $* * *$ & $*$ & $* * *$ \\
\hline & $\mathrm{B} \times \mathrm{P} \times \mathrm{Y}$ & $* *$ & ns & ns & ns & $* * *$ \\
\hline & B x TG x Y & $* * *$ & ns & ns & ns & $* * *$ \\
\hline & $\mathrm{P} \times \mathrm{TG} \times \mathrm{Y}$ & $\mathrm{ns}$ & ns & ns & ns & $* * *$ \\
\hline
\end{tabular}

BGTB (B), plant growth promoting rhizobacteria; TG, tavuk gübresi; P, fosforlu gübre; Y, yıl; büyük harfle gösterilen değerler \% 1 $(\mathrm{P}<0.01)$, küçük harfle gösterilen değerler \% $5(\mathrm{P}<0.05)$ önemlidir

çevre koşulları gibi birçok etkene bağlı olduğu belirlenmiştir (Şahin et al 2004; Çakmakcı et al 2006).

İlk yıla göre ikinci y1l fosforlu gübre uygulaması artan dozlarla beraber bakla sayısını önemli ölçüde artırmıştır. Bu durum P x Y interaksiyonunun önemli çıkmasına neden olmuştur (Şekil 1b). İkinci yıl ilk yıla göre yağışın daha fazla olması ve sıcaklığın daha yüksek olması nedeniyle fosfor alımı teşvik edildiği için bitkilerde bakla sayısı artmış olabilir. Çünkü düşük toprak sıcaklığı bitkilerde fosfor alımını kısıtlayan önemli bir çevre faktörüdür (Connor et al 2011). Nitekim artan fosfor alımina bağlı olarak baklagillerde bakla sayısının arttığı farklı araştırıcılar tarafından rapor edilmiştir (Abid et al 2002; Çetin \& Öztürk 2012). 


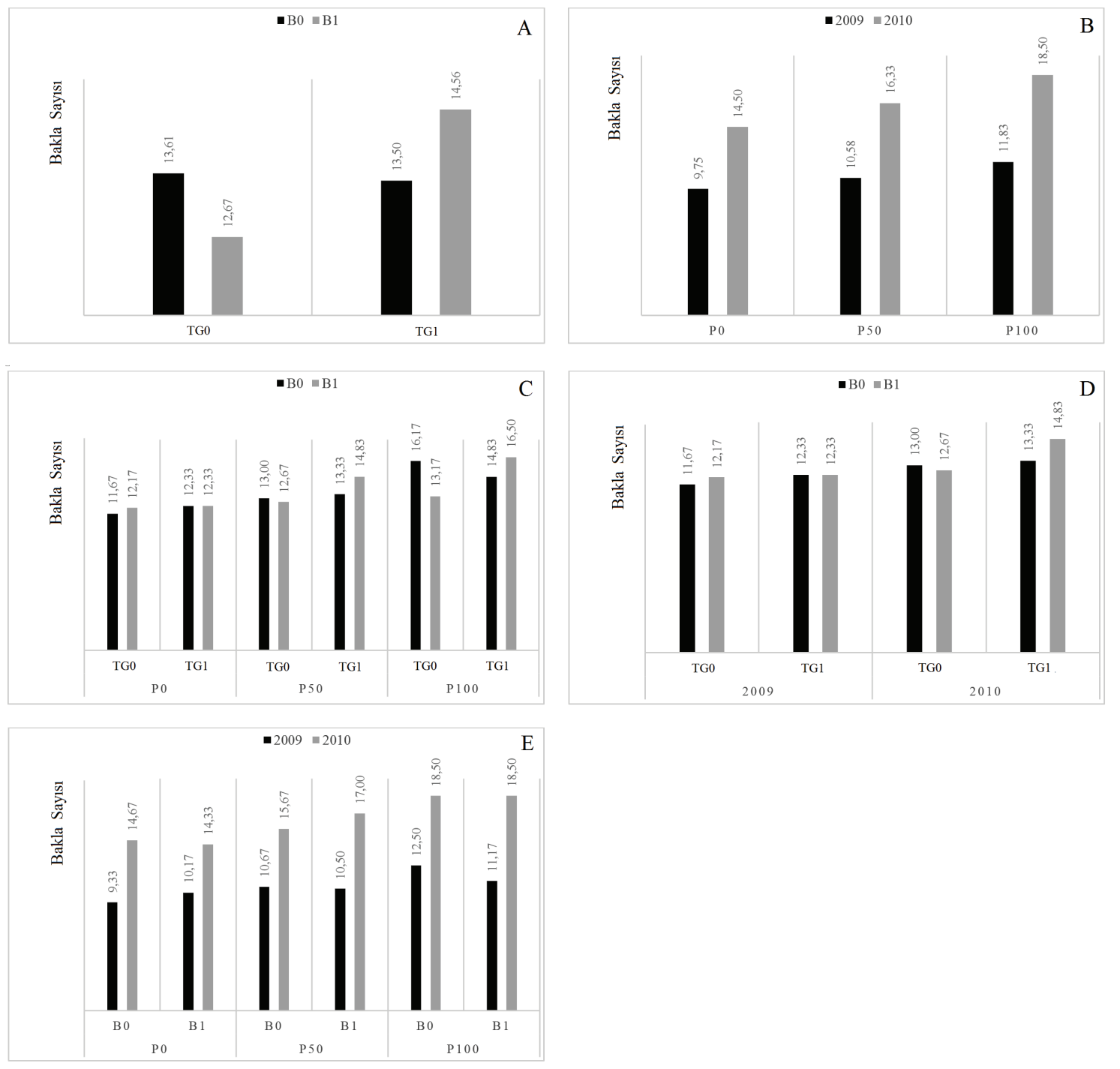

Şekil 1- a,b,c,d,e: Bakteri, fosfor ve tavuk gübresi uygulamalarının Macar fiğinde bakla sayısı üzerine etkileri; B x TG, Y x P, B x P x TG, B x TG x Y, B x P x Y

Figure 1-a,b,c,d,e-Effects of bacteria, phosphorus fertilizer, and chicken manure applications on number of pods in Hungarian vetch; ; $B \times T G, Y \times P, B \times P \times T G, B \times T G \times Y, B \times P \times Y$

Fosfor gübresi uygulanmayan parsellerde tavuk gübresiyle beraber bakteri uygulaması bakla sayısını etkilemezken, hektara $50 \mathrm{~kg}$ fosfor uygulanan parsellerde tavuk gübresi uygulanmadığında bakteri uygulamasının etkisi görülmezken, tavuk gübresi uygulandığında bakla sayısında belirgin bir artış olmuştur. Hektara $100 \mathrm{~kg}$ fosfor uygulanan parsellerde ise tavuk gübresi uygulanmadığında BGTB uygulaması bitkide bakla sayısını azaltırken, tavuk gübresi uygulamasıyla belirgin bir artışa 
sebep olmuştur (Şekil 1c). Bu farklı tepki sonucu B x P x TG interaksiyonu önemli olmuştur (Şekil 1c). $\mathrm{Bu}$ durum toprakta değişen besin elementi konsantrasyonuna bağlı olarak bakterilerin farklı tepki göstermesinden kaynaklanmıştır. Nitekim benzer sonuçlar Çakmakçı et al (2006) tarafindan da ortaya konulmuştur.

İlk y1l tavuk gübresi uygulanan ve uygulanmayan parsellerde BGTB aşılaması bitkide bakla sayısını etkilemezken, ikinci yılda tavuk gübresi uygulanan parsellerdeki bakteri aşılaması bitkide bakla sayısını belirgin bir şekilde artırmıştır. Ortaya çıkan bu durum Y x B x TG interaksiyonunun önemli çıkmasına neden olmuştur (Şekil 1d).

İkinci yıl iklim ve toprak şartlarının farklılığından dolayı gübre ve BGTB etkinliği değişmiş, bakteri ve tavuk gübresinin beraber kullanımı bakla sayısını önemli derecede artırmıştır. Nitekim yapılan çalışmada organik gübre ve BGTB uygulamasının beraber kullanımının bakla sayısını ve verimi $\operatorname{artırdığı~belirlenmiştir~(Javaid~\& ~Mamood~2010).~}$

Fosfor uygulanmayan parsellerde ilk yıl BGTB aşılaması bitkide bakla sayısını artıırken, ikinci yılda etkili olmamıştır. Hektara $50 \mathrm{~kg}$ fosfor uygulamasında ise bakteri aşılması ilk yıl etkisiz olurken ikinci yıl pozitif etki yapmıştır. Hektara 100 $\mathrm{kg}$ fosfor uygulamasında ise ilk yıl bakteri aşılaması negatif etki yaparken ikinci yılda etkisiz olmuştur. $\mathrm{Bu}$ farklı tepki sonucu Y x B x P interaksiyonu önemli olmuştur (Şekil 1e).

$\mathrm{Bu}$ durum besin elementlerinin yarayışlılı̆̆ının mikroorganizma faaliyetine bağlı olması (Whitehead 2000) ve fosforlu gübreyle organik gübrenin beraber kullanımının daha etkin olmasının (Lanyasunya et al 2006) etkisiyle ortaya çıkmış olabilir. Nitekim yapılan çalışmalarda da kimyasal gübre, organik gübre ve BGTB uygulamalarının beraber uygulanmasının ot verimi, tohum verimi ve bakla sayısını artırdığı belirlenmiştir (Kumar et al 1999; Mirshekari et al 2012).

BGTB uygulaması Macar fiği ana dal sayısını önemli $(\mathrm{P}<0.01)$ derecede artırmıştır. Benzer şekilde fosfor dozlarının artışıyla ana dal sayısındaki artış önemli belirlenmiş, tavuk gübresinin etkisi önemsiz olmuştur. Fosfor çözücü bakteriler asit fosfataz ve organik asit üreterek topraktaki organik fosforun mineralize olmasını sağlayarak (Rodriguez \& Fraga 1999) bitki gelişimini artırır. Nitekim yapılan çalışmada da gerek beraber gerekse ayrı ayrı bakteri ve fosfor uygulamasının ana dal sayısını artırdığı belirlenmiştir (Assiouty \& Sedera 2005).

Fosfor ve tavuk gübresi uygulanmayan parsellerde bakteri uygulaması ana dal sayısinı artırmışken, hektara $50 \quad \mathrm{~kg} \quad \mathrm{P}_{2} \mathrm{O}_{5}$ uygulanan parsellerde tavuk gübresi uygulanmadığında BGTB etkili olmamış fakat tavuk gübresi uygulandığında ana dal sayısında belirgin bir artış olmuştur. Özellikle tavuk gübresi ile BGTB'nin birlikte uygulamasının olumlu etkisi $100 \mathrm{~kg} \mathrm{ha}^{-1}$ fosfor uygulanan parsellerde çok belirgin olmuştur. $\mathrm{Bu}$ farklı tepki sonucu B x F x TG interaksiyonu önemli olmuştur (Şekil 2). Kimyasal ve organik gübreyle bakteri aşılaması beraber uygulandığında verimi daha çok artırdığg bilinmektedir (Mishra et al 2010). Gübreleme yoluyla toprağa verilen fosfor ya da bitkiye yarayışsız halde bulunan fosfor bakteriler tarafından elverişli hale getirilir.

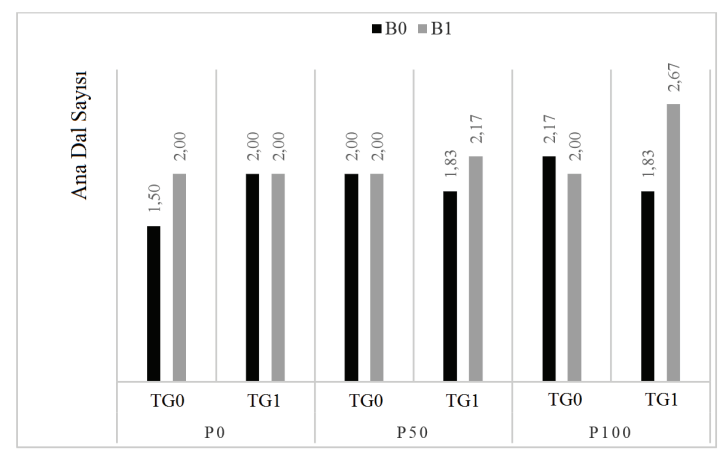

Şekil 2- Bakteri, fosfor ve tavuk gübresi uygulamalarının Macar fiğinde ana dal sayısı üzerine kombine etkisi; B x P x TG

Figure 2- Combine effects of bacteria, phosphorus fertilizer and chicken manure applications on number of main branches in Hungarian vetch; $B \times P \times T G$

Bakteri uygulamas1 baklada tane sayısinı azaltırken $(\mathrm{P}<0.01)$, fosforlu gübre ve tavuk gübresi uygulaması artışa sebep olmuştur $(\mathrm{P}<0.01)$. 
Ayrıca yıllar arasında da önemli $(\mathrm{P}<0,01)$ farklılık belirlenmiştir (Çizelge 2).

Her iki yılda da BGTB uygulaması baklada tane sayısını düşürmüştür, bakteri uygulanmayan parsellerde baklada tane sayısı ikinci yıl daha yüksek tespit edilmiştir. $\mathrm{Bu}$ durum $\mathrm{B} \times \mathrm{Y}$ interaksiyonunun önemli $(\mathrm{P}<0.01)$ çıkmasına neden olmuştur (Şekil 3a).

Fosfor uygulanmayan ve hektara $50 \mathrm{~kg} \mathrm{P}_{2} \mathrm{O}_{5}$ fosfor uygulanan parsellerde BGTB uygulamas1 baklada tane sayısını azaltmışken, hektara $100 \mathrm{~kg}$ $\mathrm{P}_{2} \mathrm{O}_{5}$ fosfor uygulanan parsellerde artırmıştır. $\mathrm{Bu}$ farklı tepki sonucu B x P interaksiyonunu önemli $(\mathrm{P}<0.01)$ çıkmıştır (Şekil 3b)

Tavuk gübresi uygulanmayan parsellerde BGTB uygulaması baklada tane sayısını artırmışken, tavuk gübresiyle beraber bakteri uygulaması düşürmüştür. $\mathrm{Bu}$ durum $\mathrm{B}$ x TG interaksiyonunun önemli $(\mathrm{P}<0.01)$ çıkmasına neden olmuştur (Şekil 3c). Fosfor uygulanmayan ve hektara $50 \mathrm{~kg} \mathrm{P}_{2} \mathrm{O}_{5}$ uygulamasında tavuk gübresi uygulaması baklada tane sayısını önemli ölçüde artırırken, $100 \mathrm{~kg} \mathrm{P}_{2} \mathrm{O}_{5}$ uygulamasında etkisi önemsiz olmuştur. $\mathrm{Bu}$ farklı tepki sonucu $\mathrm{P}$ x TG interaksiyonu önemli $(\mathrm{P}<0.01)$ çıkmıştır (Şekil 3d).

$\mathrm{Bu}$ durum tavuk gübresi de fosfor yönünden zengin bir gübre olduğundan hektara $50 \mathrm{~kg}$ $\mathrm{P}_{2} \mathrm{O}_{5}$ dozuyla beraber uygulandığında optimum verim sağlamasından olabilir. $50 \mathrm{~kg}$ dozuyla beraber optimum verim elde edildiğinden $100 \mathrm{~kg}$ uygulamasında bir etki yapmamış olabilir.

BGTB uygulaması Macar fiğinde tohumun 1000 tane ağırlığını önemli $(\mathrm{P}<0.05)$ derecede artırırken,
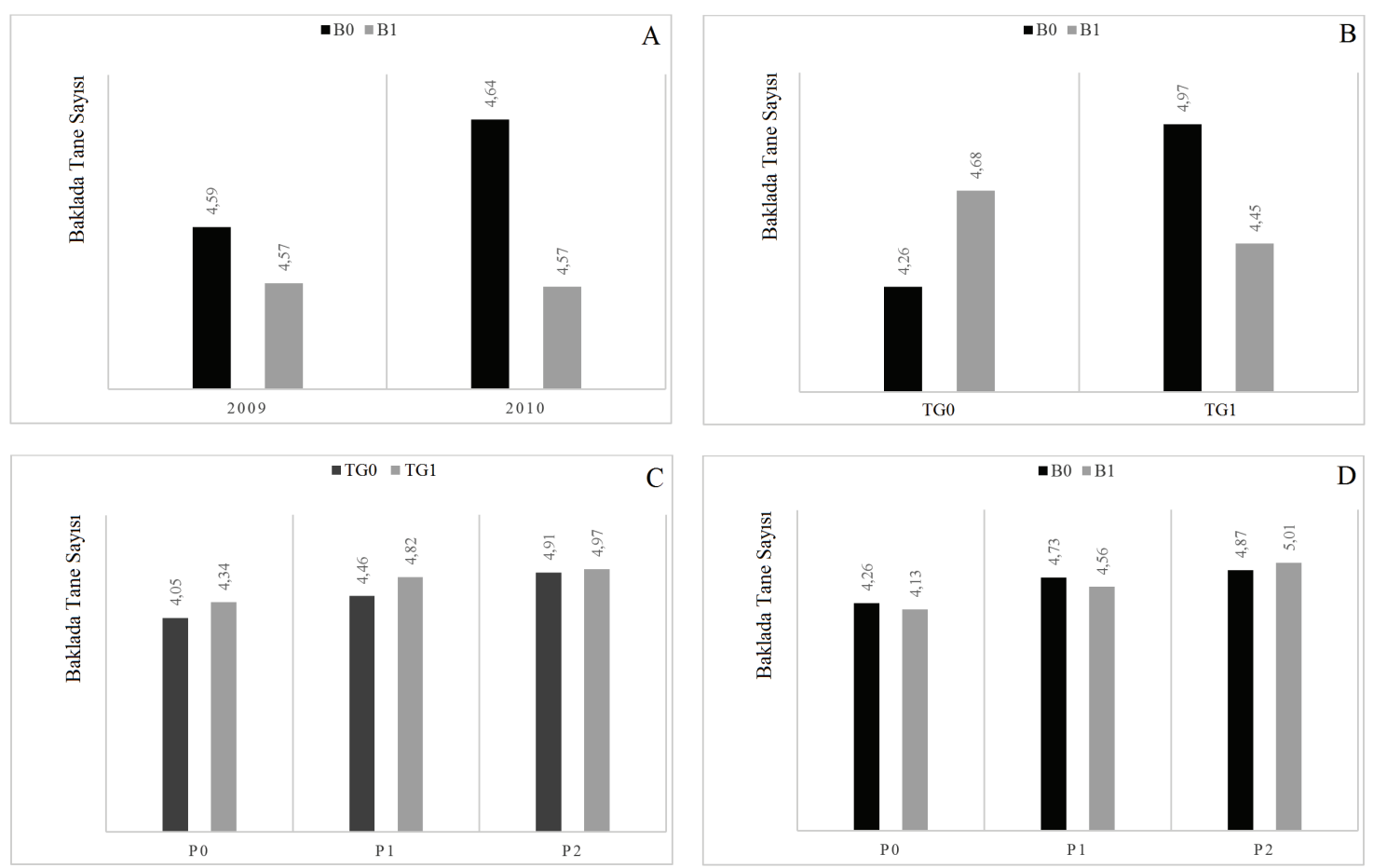

Şekil 3- a,b,c,d: bakteri, fosfor ve tavuk gübresi uygulamalarının Macar fiğinde baklada tane sayısı üzerine etkileri; B x Y, B x P, B x TG, P x TG

Figure 3-a,b,c,d, effects of bacteria, phosphorus fertilizer, and chicken manure applications on seed number per pod in Hungarian vetch; $B \times Y, B \times P, B \times T G, P \times T G$ 
tavuk gübresinin etkisi önemsiz belirlenmiştir (Çizelge 2). Fosfor gübresi uygulaması dozların artışıyla birlikte 1000 tane ağırlığı da doğrusal olarak artmıştır $(\mathrm{P}<0.01)$. Yıllar arasında da önemli $(\mathrm{P}<0.05)$ farklılık belirlenmiştir. Nitekim yapılan çalışma da artan fosfor dozlarıyla 1000 tane ağırlığının arttığı tespit edilmiştir (Abid et al 2002).

BGTB uygulaması fosforun uygulanmadığ 1 ve hektara $50 \quad \mathrm{~kg} \quad \mathrm{P}_{2} \mathrm{O}_{5}$ uygulamasinda tavuk gübresi uygulanmayan parsellerde 1000 tane ağırlığında artış sağlamışken, hektara $100 \mathrm{~kg} \mathrm{P}_{2} \mathrm{O}_{5}$ uygulamasında az miktarda azalışa neden olmuştur. Tavuk gübresi uygulanan parsellerde ise BGTB uygulaması fosfor uygulanmayan ve hektara 50 $\mathrm{kg} \mathrm{P}_{2} \mathrm{O}_{5}$ uygulamasında 1000 tane ağırlığında az miktarda azalışa neden olmuşken, hektara $100 \mathrm{~kg}$ $\mathrm{P}_{2} \mathrm{O}_{5}$ uygulamasında artışa neden olmuştur. $\mathrm{Bu}$ farklı tepki sonucu B x P x TG interaksiyonu önemli çıkmıştır (Şekil 4).

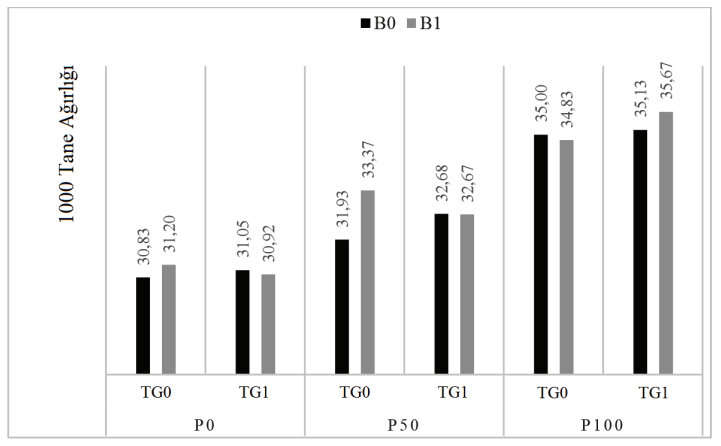

Şekil 4- Bakteri, fosfor ve tavuk gübresi uygulamalarının Macar fiğinde 1000 tane ağırlığı üzerine kombine etkisi B x P x TG

Figure 4- Combine effects of bacteria, phosphorus fertilizer and chicken manure applications on 1000 grain weight in Hungarian vetch; $B \times P \times T G$

BGTB ve fosforlu gübre uygulamaları tohum verimini önemli $(\mathrm{P}<0.01)$ ölçüde artırmıştır. Artan fosfor dozları tohum verimini doğrusal olarak artırmıştır. Tavuk gübresinin tohum verimine belirgin bir etkisi olmamıştır. Denemenin ikinci yılında ilk yıla göre daha yüksek tohum verimi kaydedilmiştir (Çizelge 2). Nitekim yapılan çalışmada da BGTB aşılamasının tohum verimini artırdığı belirlenmiştir (Freitas et al 1997).

İlk yıl tavuk gübresi uygulaması tohum veriminde kısmi bir artışa sebep olurken, ikinci yılda tersi bir durum ortaya çıkmıştır. Bu durum Y x TG interaksiyonunun önemli çıkmasına neden olmuştur (Şekil 5a).

Her iki yılda da artan fosfor dozları tohum verimini artırmıştır. Ancak ikinci yılda fosfor dozunun $50 \mathrm{~kg} \mathrm{ha}^{-1}$ 'den $100 \mathrm{~kg} \mathrm{ha}^{-1}$ 'e çıkmasıyla ortaya çıkan artış çok daha yüksek olduğu için Y x P interaksiyonu önemli olmuştur (Şekil 5b).

Artan fosforlu gübre uygulamalariyla beraber BGTB uygulaması tohum veriminde önemli bir artış sağlamıştır. Bu birlikte etki $100 \mathrm{~kg} \mathrm{ha}^{-1}$ fosfor dozunda çok daha belirgin olmuştur. $\mathrm{Bu}$ durum B x P interaksiyonunun önemli çıkmasına neden olmuştur (Şekil 5c). BGTB aşılaması ve fosforlu gübrelemenin bitki gelişimi ve tohum verimini artırdığı birçok çalışmada belirlenmiştir (Verma 2000; Bhat et al 2013). BGTB uygulaması tavuk gübresiyle beraber verimi daha çok artırırken BGTB uygulanmayan parsellerde tavuk gübresi uygulamas1 verimi düşürmüştür. Bu farklı tepki sonucu $\mathrm{B}$ x TG interaksiyonu önemli çıkmıştır (Şekil 5d).

Her iki yılda da BGTB uygulaması uygulanmayan parsellere göre artan fosfor dozlariyla beraber tohum verimini artırmıştır. İkinci yıl bu artış daha belirgin olmuştur. $\mathrm{Bu}$ durum $\mathrm{Y}$ x B x P interaksiyonunun önemli çıkmasına neden olmuştur (Şekil 5e).

İlk yıl tavuk gübresi uygulanmadan BGTB uygulaması verimi önemli derecede artırırken, ikinci yıl bu etki önemli olmamıştır. Her iki yılda da BGTB ve tavuk gübresinin beraber uygulanmalarının verimi artırdığı, bu artışın ikinci yıl daha belirgin olduğu tespit edilmiştir. Bunun sonucu olarak Y x B x TG interaksiyonunun önemli çıkmasına neden olmuştur (Şekil 5f).

$\mathrm{Bu}$ durum muhtemelen ikinci y1l daha sicak geçtiğinden bakteri etkinliğinin artmasından dolayı olabilir. Nitekim BGTB etkinliğinin çevre koşulları ve toprak besin elementi içeriğine göre değiştiği bilinmektedir (Pal 1998; Çakmakçı et al 2006). 


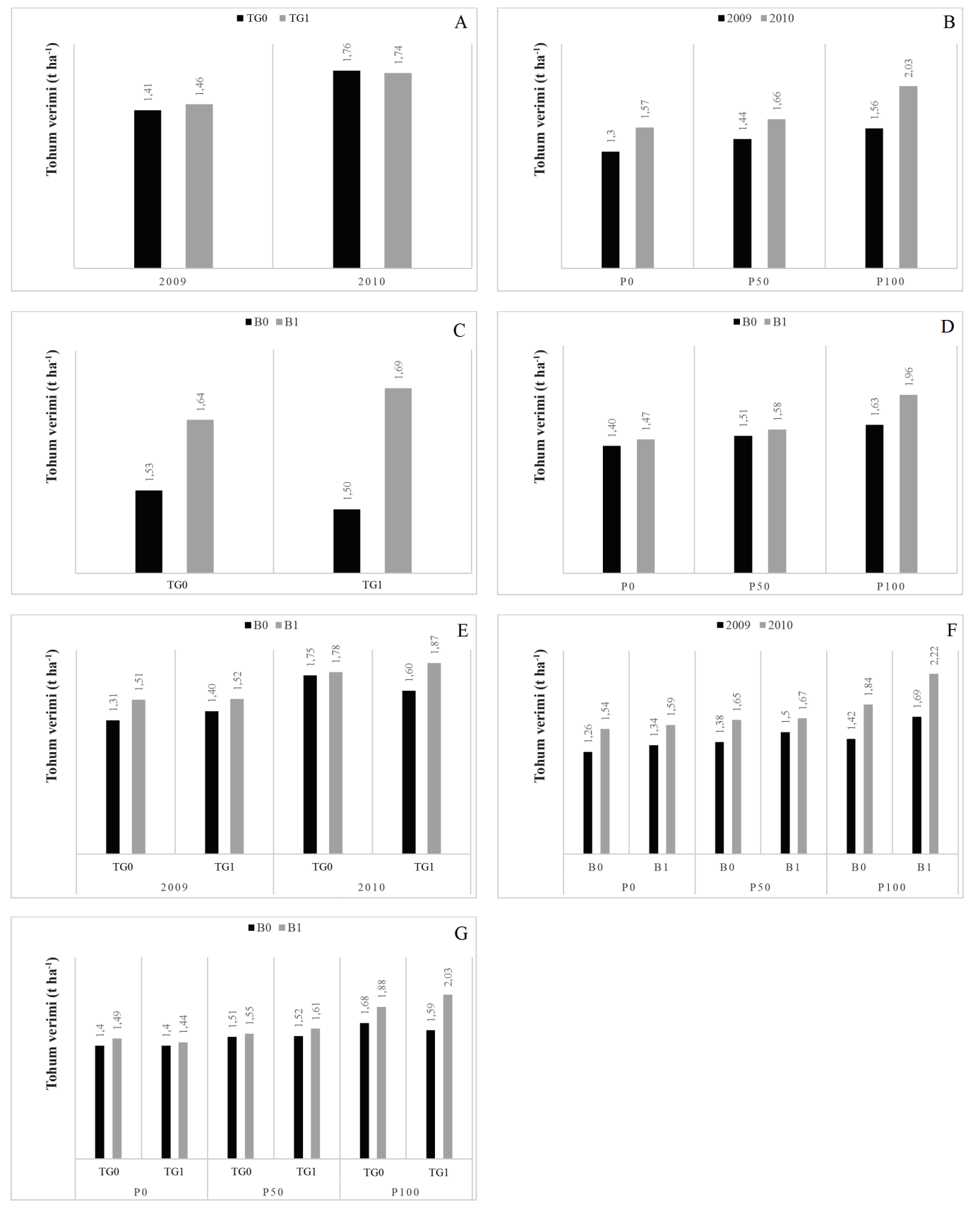

Şekil 5- a,b,c,d,e,f: bakteri, fosfor ve tavuk gübresi uygulamalarının Macar fiğinde tohum verimi üzerine etkileri; TG x Y, Y x P, B x TG, B x P, B x TG x Y, Y x B x P, B x TG x P

Figure 5-a,b,c,d,e,f: effects of bacteria, phosphorus fertilizer, and chicken manure applications on seed yield in Hungarian vetch; TG $\times Y, Y \times P, B \times T G, B \times P, B \times T G \times Y, Y \times B \times P, B \times T G \times P$ 
Fosforlu gübre uygulanmayan parsellerde tavuk gübresi ve BGTB tohum verimi üzerine belirgin bir etki yapmazken, hektara $50 \mathrm{~kg}$ fosfor uygulandığında tavuk gübresine ilaveten bakteri aşılamasının, hektara $100 \mathrm{~kg}$ fosfor uygulandığında ise tavuk gübresi olsun veya olmasın tohum veriminde belirgin bir artış ortaya çıkmıştır.

Değişen uygulamalara bağlı olarak ortaya çıkan farklı tepkiler B x P x TG interaksiyonu önemli çıkmasına sebep olmuştur (Şekil 5g). Fosfor bitkide generatif gelişmeyi teşvik ettiğinden, fosforlu gübrelemeyle beraber tohum veriminin artması olas1 bir durumdur. Ayrıca fosforlu gübrelemeyle birlikte fosfor çözücü bakteri beraber kullanıldığında bitkiler tarafindan fosfor alımı artacağı için yüksek fosfor alımına bağlı olarak tohum verimi artırmış olabilir (Srivastava \& Ahalawat 1995). Nitekim kimyasal ve organik gübrelerle beraber bakteri aşılamasının beraber uygulanmasinın tohum verimini artırdı̆̆ belirlenmiştir (Mishra et al 2010).

\section{Sonuçlar}

Sonuç olarak Macar fiğinde tohum verimi ve verim unsurlarına bakteri aşılaması, tavuk gübresi ve fosforlu gübrelemenin etkilerinin ele alındığ bu çalışmada bakteri uygulamasının yıllara göre farklı tepki verdiği belirlenmiştir. İki yıllık ortalama sonuçlara ait BGTB $\mathrm{x}$ tavuk gübresi $\mathrm{x}$ fosfor interaksiyonu dikkatli incelendiğinde bakteri ve tavuk gübresinin ayrı ayrı veya birlikte uygulanması fosforlu gübreye alternatif olmadığını, hatta bunların fosforlu gübre ile birlikte uygulandığında en yüksek tohum verimini sağladığ 1 görülmektedir. $\mathrm{Bu}$ sonuçlara göre fosfor yününden fakir veya orta seviyedeki yüksek rakımlı alanlarda Macar fiğinde tohum üretimi için hektara $100 \mathrm{~kg} \mathrm{P}_{2} \mathrm{O}_{5}$ 'e ilaveten 3 ton tavuk gübresi verilmesi ve fosfor çözücü bakteri aşılamasının en iyi sonucu verdiği görülmektedir. Bu sonuçlar ele alınan tavuk gübresi dozunun bakteri aşılayarak veya yalın uygulanarak yaygın fosforlu gübre uygulamasına alternatif olamayacağını, tavuk gübresinin değişen dozları veya diğer fosfor kaynakları ile birlikte fosfor çözücü bakteri çalışmalarına devam edilmesinin gerekliliğini göstermektedir. Yine denemelerde sik sik toprak fosfor seviyesinde farklılıklar ortaya çıkmakta ve bu farklılıklara bağlı olarak fosfor çözücü bakterilerin etkinliği değişmektedir. Bu durum dikkate alınarak farklı fosfor kapsamına sahip topraklarda fosfor çözücü bakterilerin rolü de irdelenmesi gereken bir diğer konu olarak karşımıza çıkmaktadır.

\section{Kaynaklar}

Abid M, Ahmad F, Ahmad N \& Ahmad I (2002). Effect of phosphorus on growth, yield and mineral composition of wheat in different textured saline sodic soils. Asian Journal of Plant Science 1(4): 472

Ano A O \& Agwu J A (2005). Effect of animal manures on selected soil chemical properties (1). Nigerian Journal of Soil Science 15: 14-19

Bhat T A, Gupta M, Ganai M A, Ahanger R A \& Bhat H A (2013). Yield, Soil Health and Nutrient Utilization of Field Pea (Pisum sativum L.) as Affected by Phosphorus and Bio-fertilizers under Subtropical Conditions of Jammu. International Journal of Modern Plant \& Animal Sciences 1(1): 1-8

Connor D J, Loomis R S \& Cassman K G (2011). Crop Ecology Productivity and Management in Agricultural Systems Second Edition, Cambridge, pp. 562

Çakmakçı R, Kantar F \& Algur Ö F (1999). Sugar beet and barley yields in relation to Bacillus polymyxa and Bacillus megaterium var. phosphaticum inoculation. Journal Plant Nutritient Soil Science 162: 437- 442

Çakmakçı R, Dönmez F, Aydin A \& Sahin F (2006). Growth promotion of plants by plant growthpromoting rhizobacteria under greenhouse and two different field soil conditions. Soil Biology \& Biochemistry 38:1482-1487

Çetin S H \& Öztürk Ö (2012). Soyada Farklı Fosfor Dozlarının Verim ve Verim Unsurları Üzerine Etkisi . Tarım Bilimleri Araştırma Dergisi 5(1): 157-161

El-Assiouty F M M \& Abo-Sedera S A (2005). Effect of Bio and Chemical Fertilizers on seed Production and Quality of Spinach (Spinacia oleracea L.). International Journal of Agriculture \& Biology 6: 947-952

Ekiz H (1983). Türkiye'de yetiştirilen bazı burçak (Vicia ervilia (L.) Willd.) çeşitlerinin önemli morfolojik biyolojik ve tarımsal karakterleri üzerinde araştırmalar. DoktoraTezi, AnkaraÜniversitesi Fen Bilimleri Enstitüsü (Basılmamış), Erzurum 
Freitas J R, Banerjee M R \& Germida J J (1997). Phosphate-solubilizing rhizobacteria enhance the growth and yield but not phosphorus uptake of canola (Brassica nopus L.). Biology and Fertility of Soils 24: 358-364

Gee G W \& Hortage K H (1986). Methods of soil analysis. Part I. Physical and Minerological Methods, In: A L Page, R H Miller \& D R Keeney (Eds), Second Edition, ASA SSSA Publisher, Agronomy. No:9 Madison, Wisconsin, USA

Javaid A \& Mahmood N (2010). Growth, nodulation and yield response of soyaben to biofertilizers and organic manures. Pakistan Journal of Botany 42: 863-871

Kadığlu S (2011).Fosforlu Gübre ve Bakteri Uygulamalarının Farklı Yem Bezelyesi Çeşitlerinin Tarımsal ve Morfolojik Özelliklerine Etkileri. Doktora Tezi, Atatürk Üniversitesi Fen Bilimleri Enstitüsü (Basılmamış), Erzurum

Kumar K, Gupta S C, Baidoo S K, Chander Y \& Rosen C J (1999). Antibiotic Uptake by Plants from Soil Fertilized with Animal Manure. Journal of Environmental Quality 34(6) : 2082-2085

Lanyasunya T P, Rong W H, Mukisira E A, Abdulrazak S A \& Ayako W O (2006). Influence of manure and inorganic fertiliser on yield and quality of Vicia villosa intercropped with Sorghum almum in Ol-Joro-Orok, Kenya. Livestock Research for Rural Development 18(10)

Marschner H (1995). Mineral nutrition of higher plants. Academic Press: London, pp. 889

Maqsood M, Hassan M U, Iftikhar M \& Mehmood M $\mathrm{T}$ (2001). Effect of different levels of phosphorus on agronomic traits of two mash bean genotypes. Pakistan Journal of Agricultural Sciences 38: 81-3

Mirshekari B, Hokmalipour S, Sharifi R S, Farahvash F \& Gadim A E K (2012). Effect of seed biopriming with plant growth promoting rhizobacteria (BGTB) on yield and dry matter accumulation of spring barley (Hordeum vulgare L.) at various levels of nitrogen and phosphorus fertilizers. Journal of Food, Agriculture \& Environment 10(3-4): 314-320

Mishra A, Prasad K \& Rai G (2010). Effect of biofertilizer inoculations on growth and yield of dwarf field pea (Pisum sativum L.) in conjunction with different doses of chemical fertilizers. Agronomy Journal 9: 163-168

Nelson R E (1982). Carbonate and Gypsum. Methods of soil analysis. Part II. Chemical and microbiological properties, In: A L Page, R H Miller \& D R Keeney (Eds.), $2^{\text {nd }}$ Edition, ASA SSSA Publisher, Agronomy. No: 9 Madison, Wisconsin, USA, pp. 191-197

Nelson D W \& Sommers L E (1982). Organic MatterMethods of soil analysis. Part II,. Chemical and microbiological properties, In: A L Page, R H Miller \& D R Keeney (Eds.), $2^{\text {nd }}$ Edition, ASA SSSA Publisher, Agronomy, No: 9 Madison, Wisconsin, USA, pp. 574-579

Olsen S R \& Sommers L E (1982). Phosphorus. Methods of soil analysis. Part II, Chemical and microbiological properties, In: A L Page, R H Miller \& D R Keeney (Eds.), $2^{\text {nd }}$ Edition, ASA SSSA Publisher, Agronomy, No: 9 Madison, Wisconsin, USA, pp. 403-427

Rodriguez H \& Fraga R (1999). Phosphate solubilizing bacteria and their role in plant growth promotion. Biotechnology Advances 17: 319-339

Sahin F, Çakmakçı R \& Kantar F (2004). Sugar beet and barley yields in relation to inoculation with $\mathrm{N}_{2}$-fixing and phosphate solubilizing bacteria. Plant Soil 265: 123-129

SAS Intstitute Inc. (2002). SAS/STAT software, version 9. SAS Institute, Inc., Cary, NC, USA

Sümerli M, Gül İ \& Yılmaz Y (2002). Diyarbakır ekolojik şartlarında Yem bezelyesi hatlarının verim ve verim öğelerinin belirlenmesi. Güneydoğu Anadolu Tarımsal Araştırma Enstitüsü Müdürlüğü Gelişme Raporları(Yayınlanmamış). Diyarbakır

Şehirali S (1997). Tohumluk ve Teknolojisi. Trakya Üniversitesi Tekirdağ Ziraat Fakültesi Matbaası, İstanbul

Tahtacıoğlu L, Avcı M, Mermer A, Şeker H \& Aygün C (1996). Bazı Kışlık Fiğ Çeşitlerinin Erzurum Ekolojik Koşullarına Adaptasyonu. Türkiye 3. Çayır-Mera ve Yem Bitkileri Kongresi, 17-19 Haziran 1996, Erzurum, s.661-667

Tan M \& Serin Y (2013). Baklagil Yem Bitkileri. Atatürk Üniversitesi Ziraat Fakültesi Ders Yayınları:190, Ders Kitabı: 177, Erzurum

Taş N (1996). Erzurum Ekolojik Şartlarında Fosforla Gübrelemenin Bazı Fiğ Türlerinin Verim ve Verim Unsurlarına Etkileri Üzerine Bir Araştırma. Yüksek Lisans Tezi, Atatürk Üniversitesi Fen Bilimleri Enstitüsü (Basılmamış), Erzurum

Pal S S (1998). Interaction of an acid tolerant strain of phosphate solubilizing bacteria with a few acid tolerant crops. Plant Soil 198: 169-177 
Srivastava T K \& Ahalawat I P S (1995). Response of pea (Pisum sativum) to phosphorus, molybdenum and bio-fertilizers. Indian Journal of Agronomy 40(4): 630-635

Subrahmaniyan K, Arulmozhi N \& Kalaiselvan P (1999). Effect of irrigation layout, irrigation and fertilizer levels on the yield of rainfed groundnut (Arachis hypogaea L.). Crop Research 18: 19-21

Uzunmehmetoğlu B \& Kendir H (2006). Yazlık ve Kışlık Ekimin Koca Fiğ (Vicia narbonensis L.) Hatlarında Tane Verimine Etkileri (Türkçe). Tarım Bilimleri Dergisi-Journal of Agricultural Sciences 12(3): 294300

Verma O P, Sangeeta P, Rathi M S \& Paul S (2000). Synergistic effect of co-inoculation of Azotobacter chrooccum and Rhizbium on pea (Pisum sativum). Annals of Agricultural Research 21: 418-20
Yıldırım O (1996). Bahçe Bitkileri Sulama Tekniği. Ankara Üniversitesi Ziraat Fakültesi Yayınları: 1438, Ders Kitab1: 420, Ankara

Yıldız N \& Bircan H (1991). Araştırma ve Deneme Metotları Atatürk Üniversitesi, Ziraat Fakültesi Yayınlar1: 266, Yayın No: 305, Erzurum

Y1ldız N (2008). Bitki Beslemenin Esaslar1 ve Bitkilerde Beslenme Bozukluğu Belirtileri. Eser Ofset Matbaac1lık, 304, Erzurum

Yolcu H, Güneş A, Güllap M K \& Çakmakçı R (2012). Effects of Plant Growth-Promotıng Rhızobacterı On Some Morphologic Characteristics, Yield And Quality Contents Of Hungarian Vetch. Turkish Journal of Field Crops 17(2): 208-214

Whitehead D C (2000). Nutrient elements in grassland. Soil-plant-animal relationships. Wallingford, UK: CABI Publishing 